\title{
River Basin Visions: Tools and Approaches from Yesterday to Tomorrow
}

\author{
Catherine Carré, Michel Meybeck, Josette Garnier, Natalie Chong, \\ José-Frédéric Deroubaix, Nicolas Flipo, Aurélie Goutte, Céline Le Pichon, \\ Laura Seguin, and Julien Tournebize
}

\section{Contents}

1 Introduction

2 Observing the Functioning of the Seine Hydrosystem Under Anthropogenic

Pressures

2.1 Strategies Devised by PIREN-Seine Scientists for the Spatiotemporal Observation of the River Basin ....

2.2 Transforming Field and Laboratory Data into an Understanding of System Functioning ....

3 From Understanding Processes to Gaining Knowledge That Supports

Decision-Making . .

3.1 Numerical Models Simulate Hydrosystem Biogeochemical Functioning Across the Land-Ocean Continuum

3.2 Models Are Used to Support Management Decisions ....

3.3 Conceptual Models Interpret Relationships Between Society and the Hydrosystem Over the Longue Durée

3.4 Models Enable Exploration of Socio-hydrosystem Scenarios and Their Consequences

3.5 Advantages and Limitations of Models for Researchers and Practitioners ........ 401

4 Participatory Devices Generated by PIREN-Seine Researchers and Their Effects

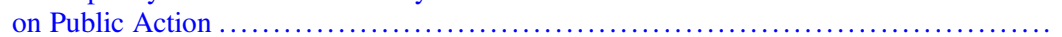

4.1 Participatory Experiments Conducted by PIREN-Seine Researchers .

C. Carré $(\square)$

LADYSS, Université Paris 1 Panthéon-Sorbonne, Paris, France

e-mail: Catherine.carre@univ-paris1.fr

M. Meybeck, J. Garnier, and A. Goutte

SU CNRS EPHE UMR 7619 Metis, Paris, France

N. Chong and J.-F. Deroubaix

LEESU, ENPC, Université Paris-Est Créteil, AgroParisTech, Paris, France

N. Flipo

Centre de Géosciences, MINES ParisTech, PSL University, Fontainebleau, France

C. Le Pichon, L. Seguin, and J. Tournebize

Irstea, HYCAR Research Unit, Antony, France 
4.2 Participatory Experiments Influence Collective Action ...................... 405

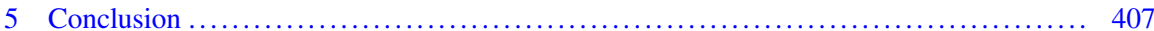

5.1 Evolution of the Programme and Scientific Methods ......................... 407

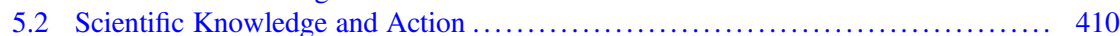

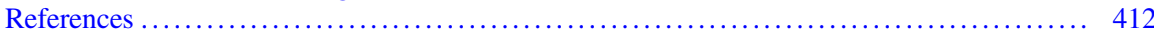

\begin{abstract}
The aim of this chapter is to provide a critical assessment of the approaches and production of tools within the PIREN-Seine programme over the past 30 years, as well as their use for river basin management and river quality improvement, and to analyse the challenges for the future. Three types of tools used in the PIREN-Seine programme are presented: metrology and fieldwork; model construction, simulation and their use in scenarios; and participatory science tools. These tools have been gradually built by the PIREN-Seine researchers and often developed together with the partners of the research programme, the main managers of the Seine River basin. Three issues raised by scientists and their partners are identified: (1) for metrology, how it has been improved to measure the state of waterbodies and to avoid their degradation; (2) for models, what they currently do and do not do and how they share common knowledge with practitioners; and (3) the place of researchers in the use of participatory devices in territories and their view of the effects of these tools to improve the quality of rivers and aquifers.
\end{abstract}

Keywords Long term, Metrology, Model, Participative tool, Quality trajectory, Scenario, Scientific production

\title{
1 Introduction
}

This analysis concerns the production of knowledge that is shared between researchers and the main managers of the Seine basin (drinking water producers and sewerage system operators, river basin agencies, watercourse unions, public institutions in charge of flood control, navigable waterway managers). Scientific knowledge is based on data produced from measurements, modelling and scenarios, while operators' knowledge is developed to jointly manage and improve the quality of the Seine River and of its aquatic environments. This way of doing science with the operational sector is similar to what Sheila Jasanoff described as a regulatory science: 'about how a fact is made and produced in this domain of scientific activity that serves public policy' [1]. As presented in the introduction of this book, since the third phase of the PIREN-Seine programme in 1998, researchers have developed a specific type of partnership research, not with laypersons but with stakeholders in charge of water management, elected officials, technicians, associations and professional groups. The tools discussed in this chapter, both numerical and conceptual, are anchored in the institutional reality of the Seine River basin, with groups of 
actors who exchange trust and legitimacy, and are therefore the product of this co-construction.

When the programme first started, the original focus was on hydrological processes (the link between river and alluvial aquifer), certain chemical pollutants (e.g. heavy metals) and certain biogeochemical methods of monitoring water quality (e.g. oxygen balance downstream of Paris, excessive algal growth). Today, the programme objective is to understand and quantify as far as possible the socioecosystem over a well-defined territory, a river basin on which multiple and varying social practices have been taking place for centuries, and to evaluate its possible future through prospective scenarios of basin evolution and its river response.

This chapter considers the way science is produced by using the paradigm developed by Gibbons et al. [2] on knowledge production and scientific discovery. 'Mode 1', which is very common, separates science and policy, and its sole purpose is the pursuit of scientific knowledge (science for the sake of science) and is defined by the domination of disciplinary science, strong internal hierarchy among disciplines and a strong sense of scientific autonomy. 'Mode 2', on the other hand, is described by Notwotny et al. [3] as socially distributed, application-oriented, transdisciplinary, diverse and heterogeneous in terms of sources and types of knowledge production, highly reflexive and subject to multiple accountabilities.

When applying Hatchuel's analysis of the position of scientists [4], it appears that PIREN-Seine knowledge production has evolved over 30 years from monodisciplinary process-based studies in the field and/or laboratory, which are characteristic of the original environmental sciences (e.g. environmental chemistry), to deterministic modelling (e.g. Seine water quality within the Parisian sector with the ProSe model), enabling technical proposals to territorial problems, and to a pluridisciplinary understanding in which the actors' rationales, decision-making and action procedures are a matter of knowledge in itself, eventually integrated into scenarios. These three stages, their potential and their limitations and perspectives in the PIREN-Seine programme are described here.

\section{Observing the Functioning of the Seine Hydrosystem Under Anthropogenic Pressures}

The scientific field studies of the PIREN-Seine do not aim only to describe the river state over the whole basin but also to fully identify and quantify the multiple hydrological, biogeochemical and ecological processes that control it. From the outset of the programme, the researchers considered these natural processes to be modified and sometimes regulated by present and past human activities and that their interactions with natural processes are always present in their research. Here, we describe the spatial and temporal scales used for this purpose. 


\subsection{Strategies Devised by PIREN-Seine Scientists for the Spatiotemporal Observation of the River Basin}

\subsubsection{Multiple and Nested Spatial Scales to Address River Basin Functioning}

The first rationale of data acquisition is spatial and complements data from the Seine Water Agency, which is based on major rivers and urban areas in the 1980s. Scientists have combined a wide range of spatial scales from plots or specific point sources to the whole Seine basin up to the basin outlet (see Fig. 10 in [5]). The upstream-downstream Paris river profile, a stretch under maximum pressure, is still a permanent feature of the programme.

\subsubsection{Multiple and Complementary Temporal Scales to Address River Basin Functioning, Regulatory Surveying and Reporting}

This second approach overlaps with the previous one. Scientists addressing the functioning of the system select the most appropriate temporal scales to cover the dominant control factors and/or river processes (Fig. 1). The hydrological phenomena are reported on the daily scale, thanks to the regulatory hydrometeorological networks. Sub-daily observation is needed in headwater streams and for storm events in urbanized areas. At the beginning of the project, intensive fieldwork was carried out over short periods, as impact studies, quarterly longitudinal profiles and bimonthly samplings performed at key stations (e.g. near the laboratory).

Hydrologically driven variability also depends on the size of the river basin intercepted at the station: flood duration ranges from a few hours for headwater streams to a few weeks for large basins $\left(100,000 \mathrm{~km}^{2}\right)$. Internal processes within the river, such as phytoplankton blooms and autochthonous formation of organic and/or inorganic particulates, last between a few days and weeks or more. Scientists are also interested in interannual variability (dry compared to wet years).

This temporal approach is largely finer than that of the regulatory chemical water quality surveys performed by river basin authorities, centralized on the monthly scale, whatever the size of the basin at the control station. Therefore, these surveys rarely capture sub-seasonal variability, and some of the river controlling factors are only taken into account statistically. Daily and sub-daily records are made by the water industries at the river intakes, on treated sewage and downstream of their outflows. These records, which are compiled for industrial monitoring or accident detection, are generally not included in river survey processing and annual or interannual state-of-the-environment reports (SOE; Fig. 1). 


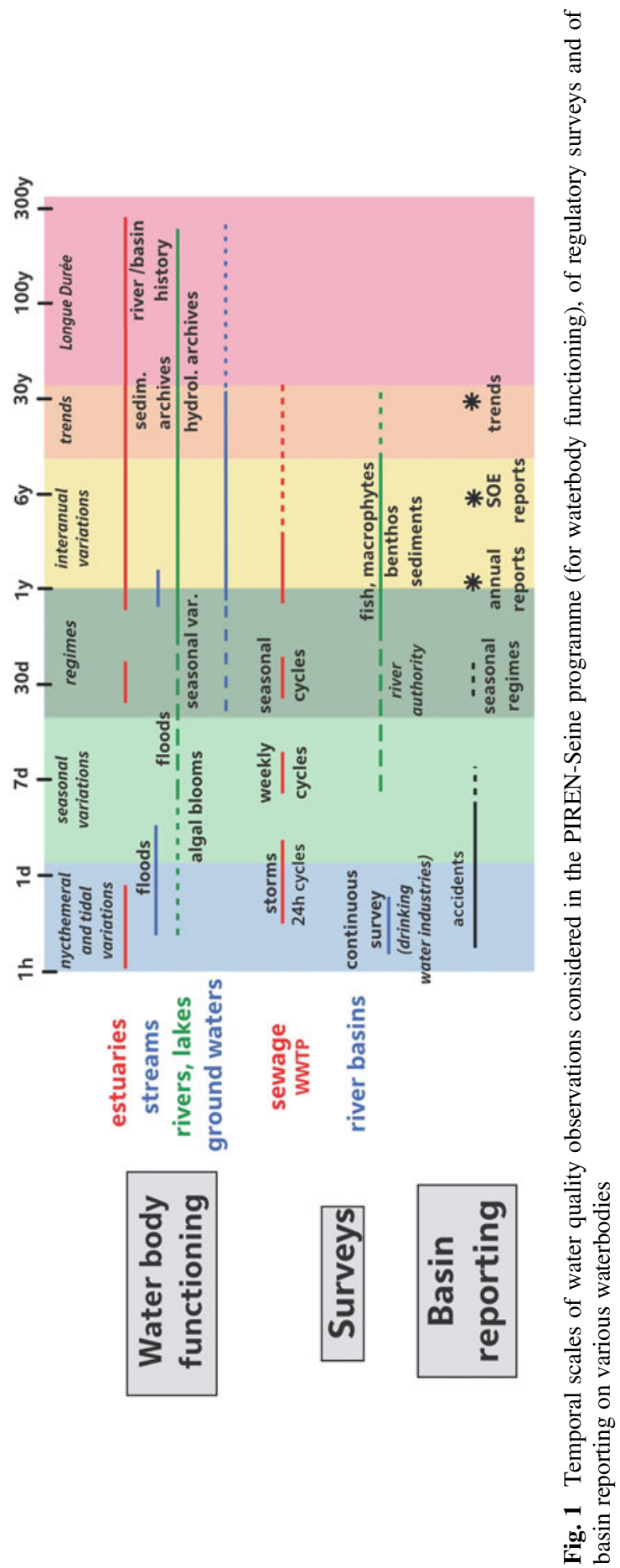


Over the past 10 years, the programme has developed a network of multiple chemical sensors that provide a continuous record of many analytes. They are mainly located in the Lower Seine, where they are used to focus on the impact caused by Paris (Box 1). Another continuous recording station has now been placed in the Orgeval experimental stream catchment (II on Fig. 1 in [5]), where it registers finescale variability in a drained agricultural basin. This monitoring generates an enormous amount of information on chemical and biogeochemical processes. The data then need to be assimilated in order to provide specific information on the real exposure of aquatic species to water quality variability.

At the opposite end of the temporal scale, the programme analyses trends over several decades (e.g. the impact of sewage treatment, the impact of phosphorus control on eutrophication and the expected hydrological changes due to climate change). Finally, the longue durée approach (50 years and more) is a specific feature of the PIREN-Seine, which aims to understand the interactions between river basins, their territories and their society. This is achieved by means of (1) historical research (e.g. [6]), (2) retrospective modelling based on data on past pressures established by scientists and on pressure-state models and (3) analysis of sedimentary archives [7].

\section{Box 1}

Simulated high-frequency measurements of river water chemistry and their use in the design of water quality surveys, using ammonia as an example.

The ProSe model generates high-frequency concentrations in the Parisian sector of the Seine River up to the estuary. This sector receives the discharges of more than 10 million inhabitants, including discharges from the Seine Aval wastewater treatment plant (SAV), Europe's largest. The upper distribution (90\%) of $\mathrm{NH}_{4}$ concentrations (left scale in Fig. 2) is simulated for the 2007-2011 period over $200 \mathrm{~km}$, according to a longitudinal profile of the Seine from Paris to the Poses station, the Seine basin outlet $[8,9]$.

Different survey frequencies are simulated here, from 15 min to 3 months. The impact of the main sewage treatment plant, Seine Aval (SAV), is best simulated when the survey frequency is less than 3 days. The summer storm events within Paris centre generate combined sewer overflows (CSOs) that generate minor ammonia peaks, with limited impact at the interannual scale. The regulatory degradation of river water quality at the SAV facility is quantified and qualified by the colour scale derived from the European Water Framework Directive (WFD). Water quality is decreased by two colour codes at the SAV facility over $10 \mathrm{~km}$ and by one scale over $130 \mathrm{~km}$, up to the Poses station. 


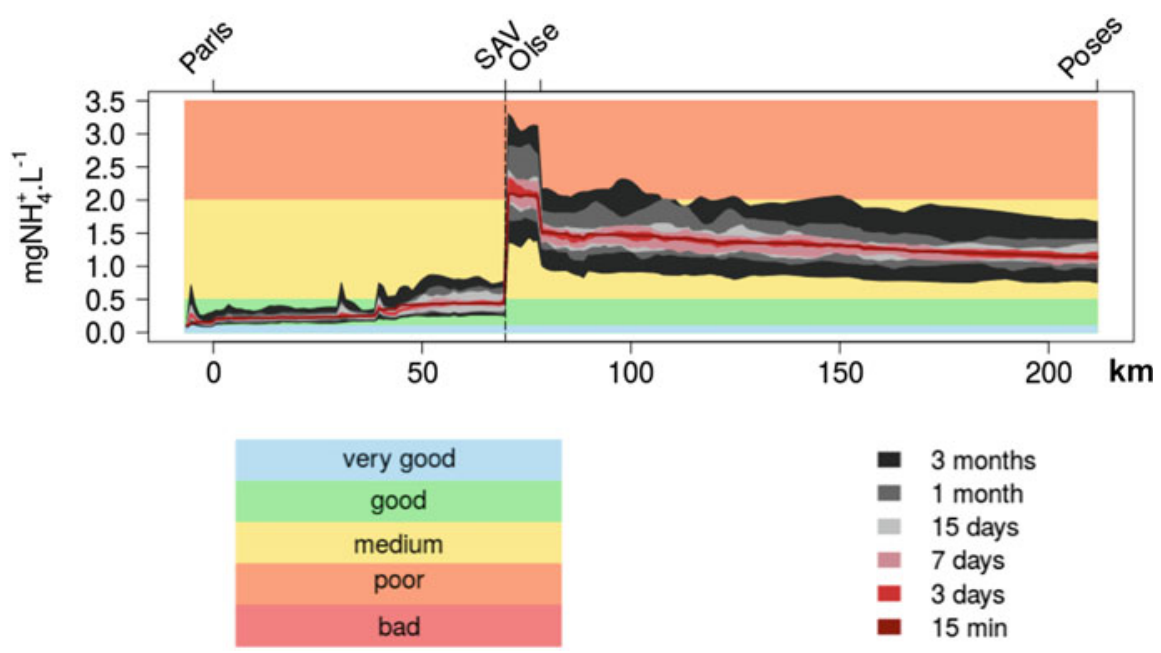

Fig. 2 Simulation of $\mathrm{NH}_{4}$ distribution for the 2007-2011 period over $200 \mathrm{~km}$ from Paris to Poses, according to several measurement frequencies from $15 \mathrm{~min} ; 3,7$ and 15 days; to 1 and 3 months (from Vilmin et al. [10])

\subsection{Transforming Field and Laboratory Data into an Understanding of System Functioning}

Targeted field studies make it possible to construct the hydrological, sedimentary and biogeochemical dynamics of the river along the stream order hierarchy and separate diffuse and point sources of material, natural and anthropogenic sources. These measurements contribute to the knowledge of the biogeochemical processes by examining the transfers between the different compartments of the Seine system and the transit times along the fluvial continuum.

\subsubsection{Basic Processes and Their Controlling Factors}

The river system is conceptualized first by a set of reservoirs (soil, plant, atmosphere, unsaturated zone, aquifers, river network) between which the material (gas, solute and particulate) is exchanged and transported (e.g. water, carbon, nitrogen). Once in the water runoff and/or in groundwaters, this material is routed from one stream order to the next and is exposed to another set of physical and biogeochemical processes (e.g. algal production, bacterial respiration, deposition/resuspension, solute-particulate exchange). Scientists measure amount in the environment, as well as rates, from which they can derive the main process parameters, which may vary spatially and temporally within the basin. These parameters integrated into conceptual frameworks are then used in the modelling at the basin scale 
(Riverstrahler and CaWaQs model) or on a specific river reach (ProSe model, Anaqualand) (see Figs. 9 and 10 in [5]).

\subsubsection{Territorial Metabolism: Comparing River Fluxes and Material Circulation in the Anthroposystem}

A major target of many biogeochemical and pollutant transfer studies is the establishment of annual to interannual material fluxes at selected river stations intercepting different types of land use and pressures, providing time- and space-integrated information on this territory. Fluxes can then be normalized by the intercepted area to generate specific ones. Both specific fluxes and annual to interannual average concentrations can be used to make comparisons within a basin, between river-borne products, and comparisons between basins, thereby making it possible to understand the spatial variability of these transfers and their controls.

The river fluxes can also be compared to the circulation of the targeted element (e.g. nitrogen, cadmium, PCBs) within the anthroposystem (i.e. import-export, product manufacturing, transportation and recycling of material, etc.). In theory, a sustainable society should not release any waste into the environment, resulting in a zero level of contamination. In reality, there is a continuous leak of waste into soils, waterbodies or the atmosphere. The amount of material circulating over a given territory is difficult to assess, since statistical data were not originally designed for environmental objectives but rather for economic or fiscal purposes. The PIRENSeine is one of the pioneers in France on the contamination of the river system by pharmaceuticals, particularly antibiotics [11]. This work has identified the sources and transfers of these products in the Seine basin, linked to human wastewater (hospitals, wastewater treatment plants) and to livestock farming. Moreover, the circulation of products should be established over basins or sub-basins, i.e. with hydrographic boundaries instead of administrative boundaries. Finally, the statistical data relate to manufactured goods, not their chemical composition, which is what would be needed for such a comparison, as in the case of individual metals, pesticides and nutrients $[12,13]$. Only few flux-flow comparisons have been made for the Seine basin, providing precious information on the socio-hydrosystem metabolism and its evolution over time. The 'leakage rates' of the basin have been assessed for heavy metals, $\mathrm{Cd}, \mathrm{Cu}, \mathrm{Hg}, \mathrm{Pb}$ and $\mathrm{Zn}$, which ranged in the 2000s from 0.1 to $10 \%$, depending on the metals [14] (see also [7] on sedimentary archives).

\subsubsection{Aquatic Biota Contamination Across Trophic Levels: A Growing Concern}

At the outset of the programme, the aquatic species (phytoplankton, zebra mussel, macrophytes) were studied as an important part of biogeochemical cycling or as indicators of the overall water quality and its restoration. Fish ecology and its disturbance by multiple human impacts (organic pollution, habitat degradation, river flow 
regulation and eutrophication) were considered as well. Harmful algal blooms observed in the outer estuary have also been addressed through dedicated models.

A new concern is the transfer of contaminants to aquatic species and from one trophic level to the next, as determined using nitrogen isotopic signatures. Primary producers (biofilm, leaf litter, macrophytes) have the lowest trophic levels, macroinvertebrates (Gammarus sp., Lymnaea sp., Corbicula sp., leech) have an intermediate trophic level, and fishes (roach, European perch, gudgeon, tench, bullhead, pumpkinseed and black bullhead) are at the top of the Seine River food web. For example, the transfer of polycyclic aromatic hydrocarbons (PAHs) and of phthalate metabolites between these trophic levels is presented in Box 2.

\section{Box 2}

Targeted monitoring of river biotic communities for PAHs, phthalates and their metabolites.

Polycyclic aromatic hydrocarbons (PAHs) and phthalates are the main organic micropollutants in the Seine hydrosystem and in three fish species [15] and prevent waterbodies from achieving good chemical status as defined by the Water Framework Directive (WFD). Biomonitoring of PAH and phthalates is complex, since they are rapidly metabolized in aquatic organisms, especially fish. Therefore, we monitored the levels of key PAH and phthalate metabolites in aquatic organisms caught in the river, from primary producers to macroinvertebrates and fish in order to assess the bioaccumulation and transfer of these pollutants and their metabolites across the trophic web [16].

The levels of PAH metabolites did not vary with trophic levels, likely due to the rapid elimination of these degradation products. We observed a trophic amplification of phthalate metabolites, probably since the excretion rate is slower (Fig. 3). This raises ecotoxicological concern, since phthalate metabolites also have deleterious effects.

\section{From Understanding Processes to Gaining Knowledge That Supports Decision-Making}

PIREN-Seine has developed a wide array of models, from numerical to conceptual. ${ }^{1}$ Numerical models aim to synthesize knowledge on the functioning of the hydrosocio-system, on the whole basin, such as Riverstrahler, or on a river sector, such as ProSe. It enables to explore the possible futures of the basin over the next

\footnotetext{
${ }^{1}$ Details on PIREN-Seine models are given in the first chapter of the book [5] and in the corresponding chapters.
} 
Polycyclic Aromatic Hydrocarbons (PAH)

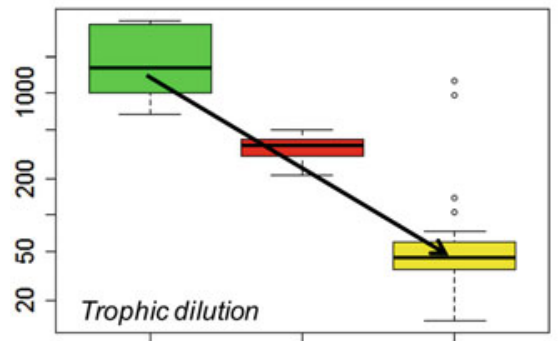

Trophic level

Phthalates

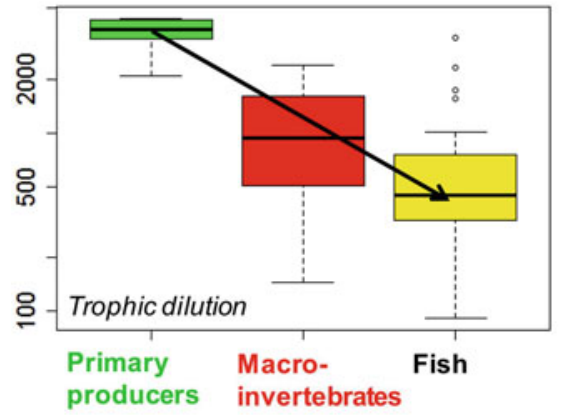

PAH metabolites

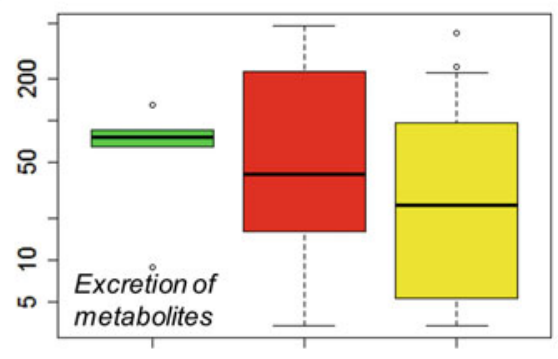

Trophic level

Phthalate metabolites

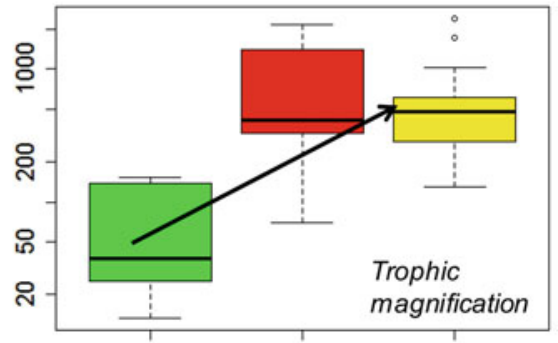

Trophic level

Fig. 3 Schematic behaviour of contaminants and their metabolites in the trophic food web of the Seine River: polycyclic aromatic hydrocarbons (PAHs), phthalates and their metabolites. Green, primary producers (biofilm, leaf litter, macrophytes); red, macroinvertebrates (Gammarus sp., Lymnaea sp., Corbicula sp., leech); and yellow, fishes (roach, European perch, gudgeon, tench, bullhead, pumpkinseed and black bullhead). Concentration in ng/g dry weight (log scales) [16]

50 years in the form of scenarios that can be used to support management decisions. Models and scenarios are conceived and developed in collaboration with PIREN-Seine partners. Their development has been presented regularly every year at the partner meetings since 1993. Conceptual models are generally developed to present a synthetic understanding of the society-basin-river evolution and interaction; their nonnumerical presentation makes them suitable for the communication of scientists' work to a lay audience. Conceptual and numerical models are also used in participatory scientific experiments, where they facilitate dialogue between water users and allow the transfer of scientific knowledge directly to the local level. 


\subsection{Numerical Models Simulate Hydrosystem Biogeochemical Functioning Across the Land-Ocean Continuum}

The models developed within the PIREN-Seine are descriptions of the components of the hydro-socio-system of the Seine basin and their relationships, through the biogeochemical processes of the hydrosystem. For example, nitric contamination is presented as resulting from the opening of the terrestrial cycle of nitrogen linked to the development of agriculture and the modern agri-food chain. The fluxes of heavy metals transferred by the river network are seen as a consequence of the flows related to the production and consumption of these metals by industrial and domestic activity, as well as of regulations. Alongside the ecology of the aquatic environment, the industrial ecology of the Seine basin system has been also considered.

One of the main outputs of the PIREN-Seine models has been to provide a general model of the contribution of groundwater to the flow of the Seine. The CaWaQS/ MODCOU model performs the hydrological and hydrogeological coupling between seven aquifer units from the recent alluvial deposits to the lower cretaceous formations, with water residence times ranging from a few months to decades. The model has recently been focused on alluvial aquifer exchanges, and operates at the daily scale with a kilometric resolution over the whole river basin, which is well suited to certain needs of the basin authorities, and is completed by the modelling of nitrate reactivity and transfer from the unsaturated zone to the aquifer. This set of models, from the soil surface and unsaturated zone to aquifers, is well suited to addressing the evolution of water resources with climate change and the scenarios of variable water demand, particularly in the agricultural sector, as well for the study of diffuse pollutants (nitrates, pesticides, atmospheric pollutants) and their evolution with possible agro-economic measures.

Several families of numerical models have been generated. Their common characteristic is their continuous evolution: More processes are taken into account, their resolution is finer, and they are extended temporally (backcasting, scenarios of the basin futures), as well as spatially (to the estuary, to other basins). Sub-models are added and gradually connected to the original ones (as presented in Box 3).

Models work with data sets acquired at different time stages. They also provide an opportunity to check data consistency with the partners. 'The models appeared also very useful for confronting the various databases gathered by Water Authorities on human pressures and those on water quality. Many incoherent data could be detected during the process of informing the models, resulting in a significant improvement of the databases and hypotheses that have been hotly debated. As far as the Water Authorities were directly concerned with the results, a real dialog was established' [17]. 


\section{Box 3}

Coupling agrosystems and hydrosystems from headwater to estuary by a model cascade for nitrogen, phosphorus and carbon circulations.

GRAFS model calculates $\mathrm{N}, \mathrm{P}$ and $\mathrm{C}$ budgets in agricultural systems [18]. From $N$ surplus, it generates nitrate leaks into the unsaturated zone [19] and into the atmosphere $\left(\mathrm{N}_{2} \mathrm{O}\right.$, a greenhouse gas; [20]). It operates from the farm scale (e.g. crop rotation, nitrogen uptake by crops, imports/exports of fertilizers, feed and food, recycling of organic residues). This diffuse nitrate is addressed in the Riverstrahler model, a semi-spatialized model organized by stream order that transfers the $\mathrm{N}$ products across the river continuum. Lateral groundwater river inputs of nitrate and local denitrification in the riparian zone are taken into account. In the river, the biogeochemical reactivity of $\mathrm{C}, \mathrm{N}, \mathrm{P}$ and $\mathrm{Si}$ species is handled by the RIVE model.

Ten-day river fluxes to the Seine estuary and to small coastal rivers are then used by the coastal zone biogeochemical model ECOMARS-3D, which was developed by marine scientists [21,22]. This model simulates estuary functioning, from Poses to Honfleur and the Bay of Seine (Fig. 4). After crossing the estuarine filter, the impact at the coastal zone of the net nutrient fluxes can be evaluated in terms of eutrophication and harmful algal proliferation. It took almost three decades and millions of Euros for around a dozen scientists to build and operationalize such a chain of models, which has been conceptualized by biogeochemists since the 1990s.

The challenge in terms of modelling the biogeochemical functioning of aquatic environments is multiple: (1) to project at multiregional scales capable of including all contributory hydrosystems from headwaters to coastal zones by proposing a quantification of flows at sea and (2) to represent at various scales the microscopic processes operating in the aquatic continua that ultimately determine basic water quality (dissolved oxygen, ammonia, phosphorus, organic carbon, etc.). The scales considered by these models range from microscopic physiological processes (bacterial activity, algal uptake of nutrients, etc.) to large spatial scales from small catchments $\left(100 \mathrm{~km}^{2}\right)$ to multiregional river basins (inputs to the North East Atlantic coast, $1,000,000 \mathrm{~km}^{2}$ ).

\subsection{Models Are Used to Support Management Decisions}

Primarily seen as research tools, models indeed allow for a better scientific understanding of the functioning of the Seine River basin while also supporting 

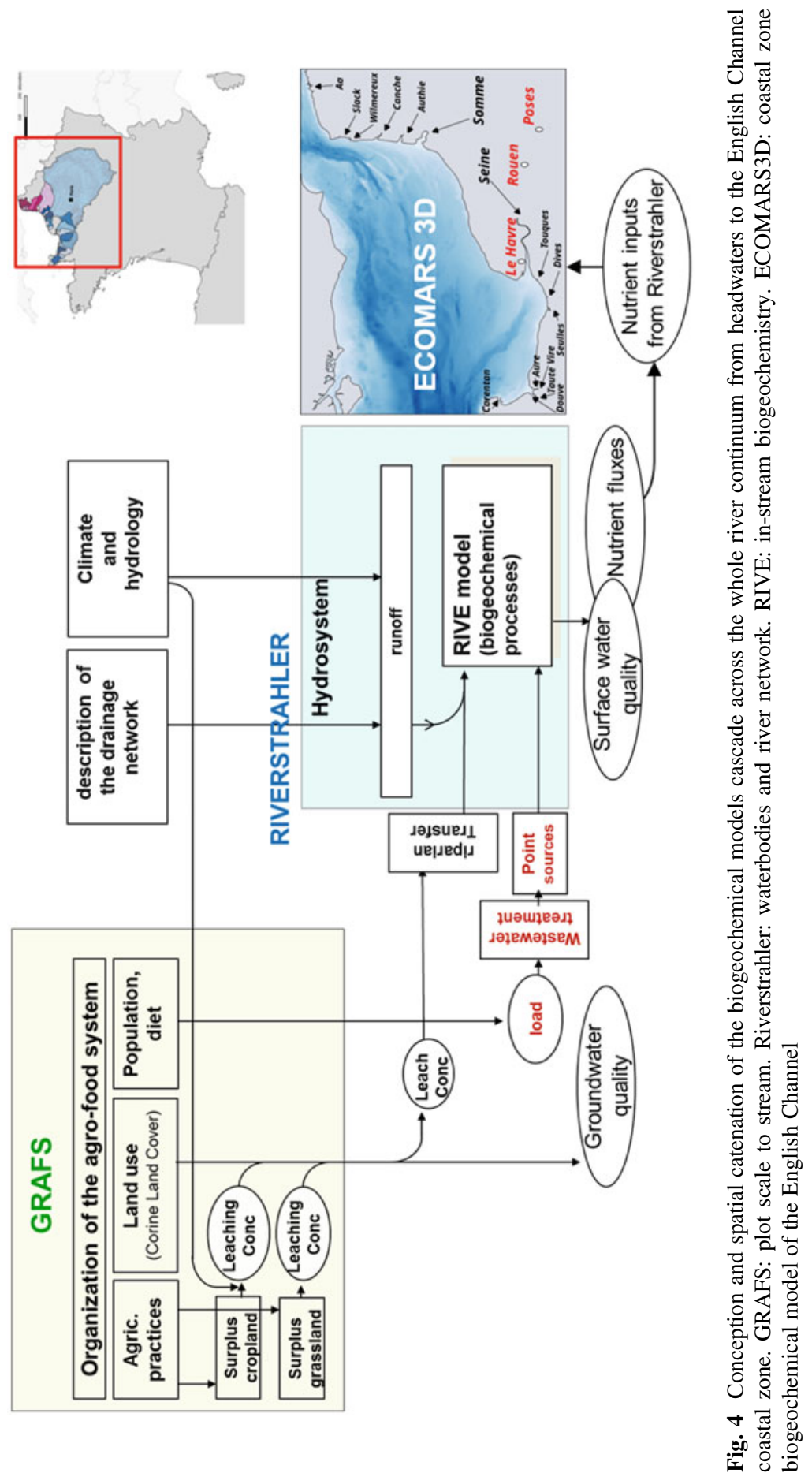
management and planning decisions. Two main tools, Seneque-Riverstrahler and ProSe, have been developed with the PIREN-Seine partners in explicit consultation.

The first use of a PIREN-Seine model as a decision-making tool was that of Seneque-Riverstrahler, at the beginning of the programme, to reflect on the different wastewater treatment options with the AESN and the SIAAP, the latter institution being in charge of the Parisian WWTPs. The model represents the major biogeochemical mechanisms of large watersheds involved in basic water quality (nutrient status, organic pollution and oxygen deficit, eutrophication). Calculations of the ecological processes are performed at a time scale of a few minutes, but results at the ecosystem scale are provided at a resolution of 10-day time stages.

Seneque-Riverstrahler (S-RS) was used to support water managers by simulating specific planning scenarios aimed at optimizing wastewater treatment in order to fulfil the implementation of the Urban Waste Water Treatment Directive in 1991 and the Water Framework Directive (WFD) in 2000. Eutrophication and oxygen depletion in the river were significantly improved, facilitating the production of drinking water and allowing for an increase in the number of fish species in the most humanimpacted area of Paris and its outskirts.

To allow its use by technicians, the Riverstrahler calculation model is embedded in a GIS environment (Seneque; [23]), a software tool that has been transferred to the Seine Water Agency (AESN) and used at the basin scale for their needs. S-RS has also been used as part of the AESN reporting requirements for good-water-status data to the European Union. It made it possible to simulate physicochemical data for river waterbodies not monitored by measuring stations.

ProSe: The fine-scale impact of Paris wastewaters on the Seine River. The ProSe model was developed from the first stage of the programme, at the request of the SIAAP, on strongly human-impacted sections of the watercourse in order to be able to deal with transitional situations, such as rainstorms and the discharges from the Parisian combined sewers and the bypasses of WWTP in the Seine. It differs from the Riverstrahler model in many ways: (1) It is a two-dimensional (2D) model based on a specific, detailed morphological description at a resolution of $100 \mathrm{~m}$; (2) it simulates highly transient events with time steps of a few minutes, averaged at the hourly scale. Dozens of combined sewage overflows, which are active during rainstorms, are localized in this model. The hydraulic behaviour of each stretch is dynamically calculated by Saint-Venant equations, and its upstream limit conditions are derived either from direct observations or from Riverstrahler simulations [17]. The biogeochemical processes (e.g. bacterial degradation of organic matter) are modelled through the RIVE model in the same way as in Riverstrahler. Today, it simulates basic water quality through more than a dozen physical chemical, biogeochemical and microbial indicators. It now covers a major section of the Seine and its tributaries within and downstream of Paris to the basin outlet.

ProSe is currently used to optimize the interannual development and sub-daily management of the sewage treatment works for the whole Paris region and its impact on water quality over several hundreds of kilometres of river length (Seine, Marne, Oise). The SIAAP operates the model to test the aquatic environment of new phosphorus and nitrogen treatments required by EU Directives for their WWTP 
and to manage their treatment facilities during repairs. It is also used by drinking water manufacturers using the river water supply. It can also be mobilized during crisis management in the case of accidental pollution, the last one being due to a fire that affected part of the Seine Aval WWTP in July 2019.

While Riverstrahler is well suited to diffuse pollution management over the whole basin and to the simulation of social responses over decades, ProSe has been designed for water quality restoration downstream of point sources of pollutants in urbanized and industrialized river sectors, from accidental pollution and rainstorm impacts to pluri-annual management. As such, both modelling approaches are fully complementary. Both models have been used by the river basin authority (Comité de basin) for the second general management scheme of the basin (SDAGE).

However, the tools themselves largely remain in the hands of researchers or practitioners with modelling expertise [24]. Only researchers have the ability to operate the model and change its code, while partners operate the model without being able to make changes in the code or benefit from the knowledge produced by modelling without operating the model or directly using its outputs. This strategy has the advantage of saving the substantial investment in time and resources required of researchers and practitioners in order to render them more accessible to nonexperts on the one hand and of developing the necessary internal expertise among practitioners on the other.

\subsection{Conceptual Models Interpret Relationships Between Society and the Hydrosystem Over the Longue Durée}

River basins and their societies coevolve over the longue durée, multi-decadal to multisecular. Since its second stage (see Figs. 9 and 10 in [5]), the PIREN-Seine has taken the view that the socio-hydrosystem was also dynamic at this temporality and that the current situation was the result of a long history of interactions between basin societies and the river. The history of the socio-hydrosystem can be presented through narratives and conceptual schematic interactions and the trajectories of the system and by extending models from the past. Compared with the factual content of an evolution, the notion of trajectory includes an interpretation of the elements selected to answer the question posed. Thus, in the example developed in Box 4, the long-standing relationship between the quality of watercourses and major European cities has been understood through the perception of pollution and its effects, as well as the measures taken by the water and sanitation services to address them [25] (Table 1).

Data to trace long-term trajectories on river state are not provided by watercourse managers, either because they do not exist or because they have not yet been exploited; they are reconstructed through (1) backward reconstruction of water 
Table 1 Technical response in terms of water and sanitation for Paris compared with Berlin, Brussels and Milan

\begin{tabular}{|c|c|c|c|c|}
\hline & Paris & Berlin & Brussels & Milan \\
\hline $\begin{array}{l}1850 \mathrm{~s} \\
\text { to } \\
1890 \mathrm{~s}\end{array}$ & $\begin{array}{l}\text { Drinking water } \\
\text { supply plant } \\
\text { Wastewater treated in } \\
\text { sewage fields/excess } \\
\text { into the Seine River }\end{array}$ & $\begin{array}{l}\text { Drinking water supply } \\
\text { plant. Installation of } \\
\text { sewage fields/excess } \\
\text { discharge rarely into the } \\
\text { Spree River }\end{array}$ & $\begin{array}{l}\text { Drinking water } \\
\text { supply plant } \\
\text { Wastewater dis- } \\
\text { charge to river }\end{array}$ & $\begin{array}{l}\text { Drinking water } \\
\text { supply plant } \\
\text { Wastewater } \\
\text { reused for } \\
\text { agriculture/ } \\
\text { excess in } \\
\text { canals }\end{array}$ \\
\hline $\begin{array}{l}1900 \mathrm{~s} \\
\text { to } \\
1950 \mathrm{~s}\end{array}$ & $\begin{array}{l}\text { Wastewater treatment } \\
\text { plants initiated in } 1940 \\
\text { (Achères-Seine Aval) }\end{array}$ & $\begin{array}{l}\text { Construction of waste- } \\
\text { water treatment plants } \\
\text { and technical } \\
\text { innovation }\end{array}$ & No change & No change \\
\hline $\begin{array}{l}1960 \mathrm{~s} \\
\text { to } \\
\text { now }\end{array}$ & $\begin{array}{l}\text { Gradual development } \\
\text { and innovation in } \\
\text { WWTPs. } \\
\text { Unguaranteed perfor- } \\
\text { mance of the system }\end{array}$ & $\begin{array}{l}\text { West Berlin continuous } \\
\text { innovation } \\
\text { Lagging in East Berlin } \\
\text { until } 1989\end{array}$ & $\begin{array}{l}\text { After 2000, con- } \\
\text { struction of the first } \\
\text { WWTP. Erratic } \\
\text { performance of the } \\
\text { system }\end{array}$ & $\begin{array}{l}\text { After } 2000, \\
\text { construction of } \\
\text { the first } \\
\text { WWTP (high } \\
\text { performance) }\end{array}$ \\
\hline
\end{tabular}

quality, using pressure-state models; (2) reconstruction of historical archives of water quality since the $1880 \mathrm{~s}$; (3) reconstruction of past contamination from sedimentary archives; (4) the construction of a unique and still growing set of data on the river and its internal and external control factors (climate and hydrology, land use, population, wastewater treatment, aquifers, urbanization and industrialization, material flow, water quality, river habitat, fish population, etc.) at fine resolutions and over 50-150 years; (5) the study of river institutions and water regulations over the past 150 years; and more (as in Box 4).

\section{Box 4}

The compared responses of four major European cities, Paris, Berlin, Milan and Brussels, to basic water quality issues faced during their urban expansion (1850-2015).

Each city has developed its own management strategy depending on water availability, policy choice, politics (when Berlin was split into two parts during the Cold War) and administrative division (the Zenne basin is managed today by three different Belgian regions). Berlin can be regarded as a precursor in terms of safeguarding its local water resources, lakes and surficial aquifers. At the end of the nineteenth century, the same water service was managing both the drinking water supply and sewage collection and treatment, both for the city and its suburban area, unlike other cities. A wide network of sewage collectors was built, and wastewater was treated on farmland around the city, which in turn was benefitting from the nutrient inputs. Three wastewater 
treatment plants were built in the 1920s when it became clear that the capacities of the sewage farms had been exceeded, whereas the Parisian sanitation organization waited until 1940 to start its first WWTP, Achères-Seine Aval. The level of treatment at Berlin's WWTPs has been constantly improved, with tertiary treatment starting in the 1980s, while in the Paris area, it was not until 1993 that all effluents were treated. Brussels water supply was far up in the Walloon region, and Milan was relying on medium-depth groundwaters, which were potentially contaminated by its own industries. Neither Milan nor Brussels had a WWTP until they were forced to do so by EU regulations at the beginning of the 2000s.

Trajectories in these four cities, which were exposed to maximum relative pressures (city population/river discharge), show a period of intense degradation in the late nineteenth century due to the discharge of untreated wastewater and the related alteration to physical environments. The rapid population growth was not followed by adequate technical, organizational or financial means sufficient to treat domestic and industrial discharges. The Zenne River was covered and transformed into a sewage collector across its urban sector. The urban impact of these cities on the quality of their rivers lasted over more than a century. The restoration of the Seine River and the Spree River was initiated several decades before that of the Zenne and Lambro rivers. European environmental policy played a major role in the converging restoration of all socio-hydrosystems in the early 2000s (Fig. 5) [25].

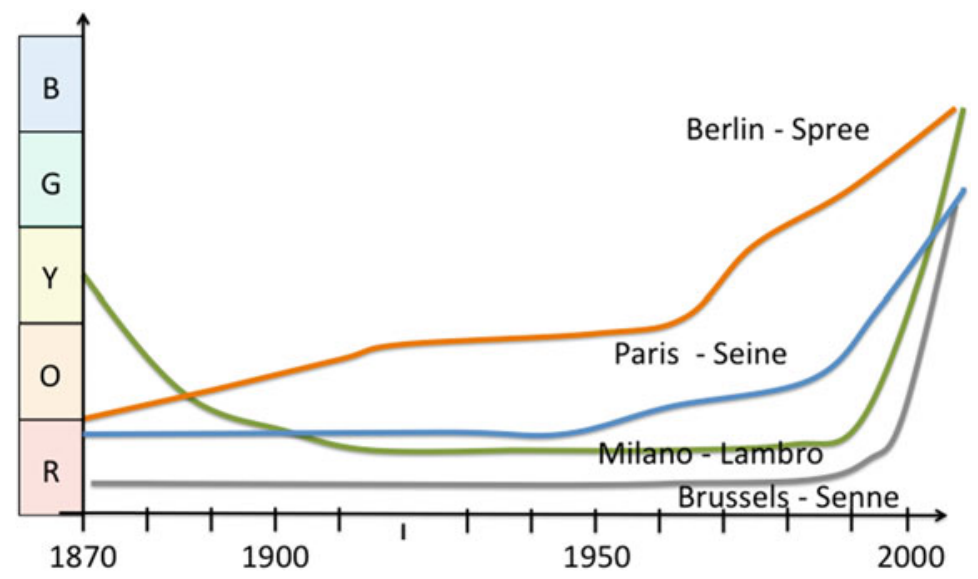

Fig. 5 Comparative trajectories (1870-2010) of the efficiency of the social response to reduce the organic pollution generated by four European cities in their rivers, using WFD standards and colour coding, from blue, very efficient policy (full river restoration), to red, inefficient measures, resulting in major degradation (summer oxygen levels occasionally below $2 \mathrm{mg} \mathrm{O}_{2} \mathrm{~L}^{-1}$ ) 


\subsection{Models Enable Exploration of Socio-hydrosystem Scenarios and Their Consequences}

Models have been spatially extended and gradually developed to incorporate more processes and interactions. On the basis of an analysis of trajectories of the major feature in the Seine basin, Riverstrahler made it possible to reconstitute the past evolution of water quality in the drainage network. A further useful feature of models is the exploration of the future of the hydro-socio-system through scenarios of sectorial changes in combination (or not) with climate change scenarios and simulation of the related river response [26]. These scenarios may simulate 'business as usual' (same trends in control factors), stepwise gradual changes or drastic changes ('what if' scenarios), which generate different sets of spatialized results on river state.

The model can be operated to feed scenarios, or the scenarios provide a new set of controlling parameters to the model and input data set. Two major approaches have been applied: (1) The preventive approach explores the possible changes in pressures on the basin, e.g. diffuse sources from agriculture; and (2) the curative approach tests the impact of river remediation measures.

\subsubsection{Preventive Approach: Simulation of Agricultural Changes in the Seine Basin}

PIREN-Seine scientists have explored the transition from a conventional intensive cropping system, which has dominated in the basin for several decades, to generalized organic production in response to new food demand for a 'demitarian' diet (reduction by half of animal product consumption). The impact of this new type of agriculture is based on an experimental agronomic field study with a set of farmers changing their agricultural practices (for more details, see Sect. 4.1). The nitrogen fluxes in soils and unsaturated areas were measured in a dozen farms over 3-6 years. These results were then incorporated in the models and upscaled to the whole basin. A realistic scenario of a deep structural agricultural change that is autonomous and organic, with a reconnection of crop, livestock and a demitarian diet, has been elaborated at the scale of the Seine basin and compared with a scenario based on good agricultural practices (see Box 5).

\section{Box 5}

Models to explore river responses to agricultural scenarios and territorial management in the Seine basin.

"We have named "territorial biogeochemistry", the branch of science that describes and tries to understand the functioning of such complex systems, 
their internal and external exchanges of material, and the (physical, chemical, biological, or social-economic) mechanisms controlling these exchanges. Here we open the way to a comprehensive and, why not, citizen-oriented way of practicing science, helping to clarify the societal choices to which we are confronted to address the threat of global change' [27].

Two contrasting scenarios have recently been developed by Billen et al. [28] for 2040. The first one represents a continuation of the current trends of opening and specialization (O/S scenario) into cropping systems based on chemically synthesized inputs, as is the case in the Seine basin. The second explores a shift to autonomy via organic farming and a reconnection of crop and livestock farming while reducing animal protein in human diets by half, the so-called demitarian diet (A/R/D scenario). These scenarios both involve the strict application of regulations on WWTPs.

The results (Fig. 6) show that the basic water quality in terms of nitrate contamination could be reduced in the upstream rivers but worsened in the downstream ones with the O/S scenario. The A/R/D scenario would considerably reduce the level in nitrate everywhere in the river network. Such a reduction in nitrate levels and fluxes would make it possible to reduce eutrophication in the coastal zone of the Bay of Seine (see [26]). Interestingly, this A/R/D scenario would reduce greenhouse gases from agriculture by $36 \%$, compared with $16 \%$ for the O/S scenario [20].

The aim of the discussion was not to define a possible future, but to encourage reflection on the possible, and sometimes conflicting, trends, such as the continuation of market openness and specialization, of agricultural territories and a sober and virtuous future with a shift to organic farming and agricultural autonomy accompanied by a change in our diet.
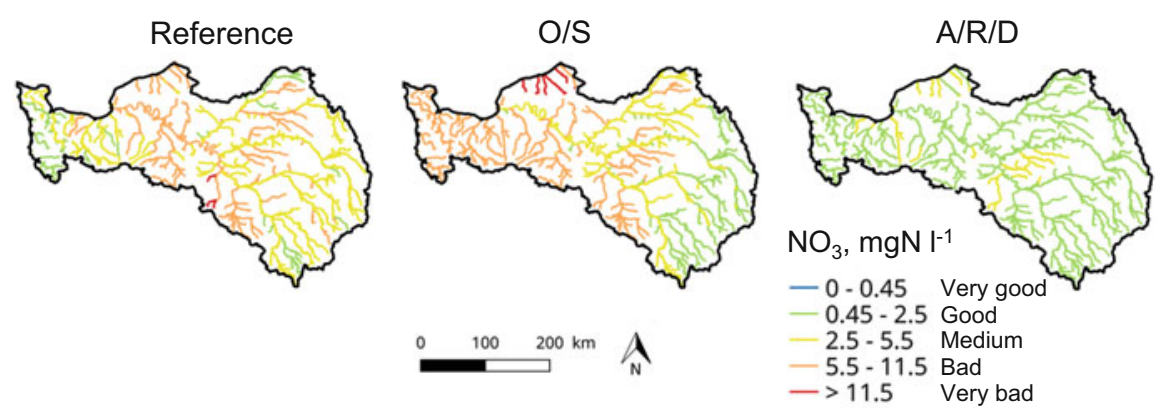

Fig. 6 Scenario outputs: spatial distribution of annual average nitrate pollution levels over the Seine Normandie river networks for the reference situation and for two contrasting scenarios for 2040: O/S, agriculture opening and specialization; A/R/D, autonomy, livestock reconnection and demitarian diet. Colour coding from blue, excellent, to red, very poor, according to the WFD (from [26]) 


\subsubsection{Curative Approach: Simulated Fish Response to the Restoration of Degraded River Habitats}

The freeware Anaqualand has been under development since 2002 at Irstea as a tool to support the development of a 'riverscape ecology' approach that explicitly considers connectivity in aquatic landscapes [29]. It was also designed to provide helpful results to bridge research and management preservation. Longitudinal and lateral connectivity for fish in rivers are modelled in $2 \mathrm{D}$, through the calculation of hydrographic or functional distances (expressed in functional $\mathrm{km}$ ). Functional connectivity is calculated according to the 'least cost' approach for which the environment facilitates or prevents the movement of fish from one life cycle habitat to another. This approach could be engaged to compare scenarios for the restoration of physical and chemical barriers that fragment river networks, thus making it possible to select priority actions and evaluate the relevance of restoration schemes for ecological continuity [30].

Anaqualand was used in the context of a SAGE (water development and management plan). Outputs from the ProSe hydraulic model were used as input parameters in Anaqualand, providing a map of fish migration probabilities based on participants' management decisions. This tool helps the local water commission (CLE) to define water resource management measures that take into account the different uses of the river. Similarly, several scenarios for restoring the ecological continuity of the Seine estuary to the Risle River for sea trout have been discussed with the Fishing Federation of the department of Eure to prioritize their actions (see Box 6).

\section{Box 6}

Modelling ecological continuity for sea trout under contrasting restoration scenarios (Anaqualand model).

The Risle River is the most downstream tributary of the Seine estuary, close to the Atlantic Ocean, and has a high potential for migratory species. It is subject to tidal influence, and no physical barriers impede the migration of fish up to Pont-Audemer, where there are a number of impassable obstacles. The Fishing Federation of the Eure department wanted to compare the actual ecological continuity of the Risle River ( 245 barriers) with 3 management scenarios for 66 barriers distributed along the main course and 2 tributaries (whereby 46 become passable and 20 are removed). In the short term, 21 initiatives are in preparation; in the medium term, 34 additional initiatives are under discussion, and in the long term, 11 more are planned.

Anaqualand models the accessibility of the Risle River, from mouth to headwaters (Fig. 7). The strong barrier effect for sea trout at Pont-Audemer is clearly shown in the present state, as well as in the short-term scenario, since no initiatives are envisaged in the near future for these most downstream 
barriers. In the medium-term scenario, the gain becomes significant, since these most downstream barriers are planned to be managed, with a total of 55 barriers becoming passable. The long-term scenario slightly improves accessibility, approaching the 'ideal' case without barriers, except for tributaries for which no management of barriers is planned as yet in the proposed scenarios.

\subsection{Advantages and Limitations of Models for Researchers and Practitioners}

Modelling tools offer numerous benefits to researchers and practitioners. They facilitate interaction and collaboration among different actors by providing a

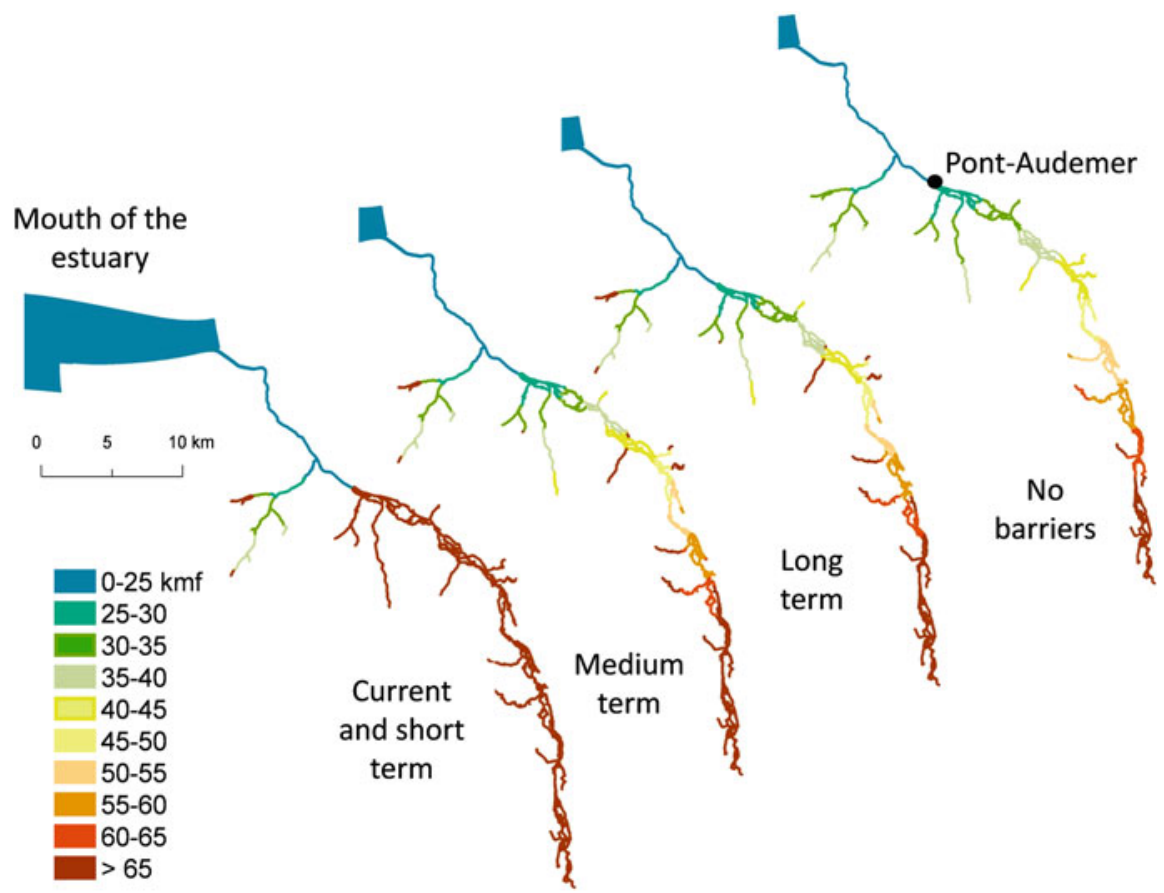

Fig. 7 Accessibility of the Risle River from the mouth of the estuary for sea trout under the different management scenarios measured by functional distances (classes of functional $\mathrm{kmf}$ ). For the purposes of visualization, lines are enlarged and do not represent the actual width of the streams [31] 
common reference. They not only provide a neutral frame for discussion, they also allow researchers and practitioners to achieve common goals without compromising individual objectives: The former conduct research to deepen their scientific understanding, while the latter gain scientific evidence to support their decisions or justify their actions. With this in mind, the PIREN-Seine's choice of expert-based models can be understood as a way of maintaining the boundaries of science and practice, since emphasis on models as research tools subject to scientific validation and backed by the recognized expertise of PIREN-Seine researchers maintains a sense of credibility, legitimacy and trust.

But they pose just as many limitations and challenges. Scenarios are simplified representations of the world with uncertainties, despite steady progress over the past decades. The communication of modelling results must be clear about this, as the results generate passionate debates within society. While modelling results may be perceived as scientifically objective, the choice of what is modelled and how it is modelled (e.g. parameters considered, processes taken into account), as well as how the results are interpreted and used, is inherently subjective. Also, the generation of model knowledge and the simulation products potentially usable by practitioners need to be issued in a 'timely' manner in relation to the way the problems arise among the epistemic community. Those works that are not put on the policy agenda of the river basin authority might not be relevant and, even less, used. The co-construction of scenarios potentially explored by models is a good way to alleviate this difficulty, since it allows for collective reflection on possible futures.

The models have made it possible to envisage a paradigm shift (e.g. the transition to organic farming, source control and reduction of pollutant emissions, single vs. multiple sewage treatment plants in the Paris region), but they may encounter some socio-economic rationales. In some sectors, such as agriculture, models have not yet produced signals strong enough to generate drastic transformations in practices or to overcome resistance to change. Also, model outputs should not contribute to the depoliticization of public decision by transferring decisions to purely technical committees. As a last point, dependence on expertise, the lack of available and/or reliable data, changing regulatory requirements demanding added functionality from the models and issues of propriety remain fundamental limitations to modelling. As a result, the Seneque model is no longer being used directly by the AESN, which now prefers to use an à la carte approach requesting modelling results from PIREN researchers when needed. The SIAAP, by contrast, has expressed a desire in recent years to move towards methods of real-time control and artificial intelligence involving the development of complex assimilation technologies [32]. It is up to researchers and their partners to see how they will develop their common patterns of practice, while the majority of operational partners still consider models to be important support tools. 


\section{Participatory Devices Generated by PIREN-Seine Researchers and Their Effects on Public Action}

The participatory imperative is not specific to water management - participatory devices are foreseen for all policies - but it is one of the principles at the heart of the WFD (Article 14). The 1992 French water law already instituted basin committees for each major river basin district and local water commission by watershed. However, all water management procedures, such as catchment supply areas to produce drinking water, needed to integrate a participatory device henceforth.

The initiatives carried out over the past 10 years have taken several forms of partnership research, with researchers in multidisciplinary teams combining environmental and social sciences. Participation is understood as a means to facilitate the connection between actors and the production of common meanings. By working on controversial topics such as modifying agricultural practices to reduce diffuse pollution, or removing river weirs to restore ecological continuity, participation should not become a tool for accepting new rules or overcoming resistance. On the contrary, it must help to collectively identify a problem and then explore various levers of action, without one solution being put forward over another. Participants do this on a voluntary basis. The facilitation methods are fundamental in order that each participant can find their place and, above all, express themselves.

\subsection{Participatory Experiments Conducted by PIREN-Seine Researchers}

The first form of partnership research is to build scientific knowledge on a territory. Some experiments are designed to feed scenarios specific to the PIREN-Seine, where participants are co-constructing the data that feed models and scenarios. Others aim to build a dialogue between actors on a controversial issue by questioning the production of scientific knowledge and its appropriation.

\subsubsection{Co-constructing Data for Models and Scenarios (ABAC Project)}

Between 2012 and 2018, the ABAC project and network involved farmers from various parts of the Île-de-France region, as well as water agencies, farmers' federations and chambers of agriculture. The project is participatory given that farmers were, as far as possible, involved in sampling operations and interpreting results. A steering committee was set up and met every year to discuss the results and possibly reorient the project. The farmers' network made it possible to compare nitrogen leaching on their farms according to their practice [33]. The database was used for scientific publications but also by regional and local partners. Verbal reports 
of the results were regularly produced during meetings and formed the basis for exchanges between the actors.

\subsubsection{Exploring River Restoration Scenarios in Model-Supported Participatory Experiments (Grand Morin Project)}

In France, the ecological management of watercourses according to the WFD partly involves weir and dam removal to restore fish and sediment circulation. This approach generates conflicts between some river users and public services. Between 2010 and 2013, a number of PIREN-Seine researchers proposed their models to the local river commission of the Grand Morin River (CLE), a tributary of the Marne to the east of the Paris, which includes public sector services, the river union, the fishermen's association, the canoe/kayak clubs, elected officials and mill owners. The expectations of the commission members at the beginning of the experiment partly reflected their divergence: for the public sector services, the experiment should facilitate weir removal by silencing the controversies over the interest in and effectiveness of levelling, whereas most members of the CLE oppose the limited and partial nature of the scientific information on the subject (ecological interest in suppressing weirs).

The ProSe model was chosen to simulate flow variations on the watercourse and the Anaqualand model for the ability of fish to move along the river. Several workshops and field trips made it possible to collectively define the question to be addressed (What happens to the river and the ecosystem by manipulating the weirs and varying the water level?) and the actors concerned. They made it possible to explain the information provided by the two models, as well as their limitations, so that the actors could evaluate for themselves the effects of the weirs on the hydraulic functioning of the river, on its uses (kayaking, mills) and the circulation of three species of fish.

The interactive platform made it possible to simulate management of the works by various actors according to objectives chosen by all the participants based on the river discharge, which was also chosen by the participants. Each participant can play a different role. The model simulates the effects of the decisions made on the chosen indicators (water level in the diverted reaches, crossing of structures by canoes or different types of fish species). The results were displayed and discussed according to the objectives of each operator. Management decisions were evaluated collectively, thereby allowing for new simulations [34].

\subsubsection{Building Territorial Dialogue to Act on Agricultural Diffuse Pollution (BRIE'eau Project)}

The BRIE'eau project (2016-2020) aims to make the particularly controversial issue of agricultural water pollution (nitrates and pesticides) in the Brie region of Seine-etMarne, a subject of debate. In this territory of large cereal crops, agricultural activity 


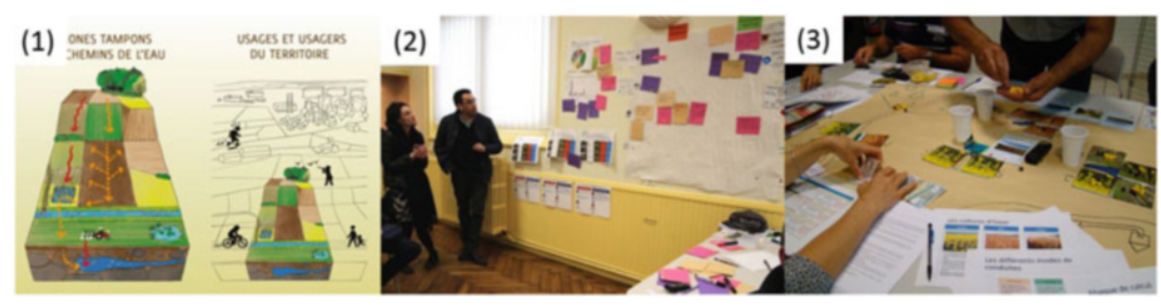

Fig. 8 An example of the cards used (1). Workshop 'Imagine together scenarios for the evolution of the territory' (2). Workshop around the role-playing game (3) (photo courtesy of IRSTEA)

has led to a sharp deterioration in water quality of the limestone groundwater of Champigny, the main groundwater resource in Île-de-France. Since 2005, AQUI'Brie, an association of users of the Champigny aquifer, and Irstea researchers have been developing local initiatives to reduce pesticide flows from drained agricultural land. Artificial wetlands have been established on agricultural plots as landscape interfaces with a hydrological buffer function, which improve water quality parameters [35].

The project consists of a joint evaluation process of these land cover devices on water quality and the improvement of biodiversity. The challenge of the participatory approach is to create the conditions for dialogue between local actors, particularly those in the agricultural and drinking water sectors. To improve water quality, two levers for action are placed at the heart of the process: changes in agricultural practices and landscape design. The participatory approach consists of three complementary steps, each of which involves a specific dialogue tool (Fig. 8): (1) a set of cards to share the diversity of perceptions on buffer zones; (2) a scenario-building tool integrating buffer zones as a possible solution [36]; and (3) a role-playing game to simulate individual and collective action to be implemented.

The cards were used during individual interviews to generate highly varying or even opposing discourses among the respondents based on a question common to all actors. The different visions were then presented in a workshop. Two contrasting scenarios were constructed and discussed: one based on maximizing farmers' gross margin and the other on minimizing pressure in plant protection products. Participants expressed what they found interesting or problematic in these scenarios and also identified priority elements for improvement. The role-playing game brought together farmers, agricultural advisors, cooperatives and elected officials responsible for drinking water in order to identify the levers and obstacles to the implementation of individual or collective initiatives.

\subsection{Participatory Experiments Influence Collective Action}

It was the researchers themselves who first benefitted from the results, with the production of new research themes, the acquisition of data and the effectiveness of the flow of knowledge produced towards the other actors. 
In the ABAC network, the collaboration with farmers who have totally or partially converted their farms to organic farming, or others who are reluctant to do so, was extremely rewarding. The community of researchers was the first to change, in terms of its science and messages to partners, with another perspective from the National Institute of Agricultural Research (INRA) on organic agriculture and the difficulties of the socioecological transition. Beyond the unifying and participatory activities, participants were looking to build up a common vision on the challenges and the means to reconcile environmentally friendly agriculture with farmers' incomes while maintaining or improving water quality.

In the Grand Morin experiment, the evaluation was carried out within the framework of a thesis [37] based on observations made during the workshops, interviews with the participants and, finally, decisions taken by the management of river works on the Grand Morin River. Concerning the mobilization of scientific knowledge, the members of the local river commission (CLE) found that, compared with the data provided by consulting firms, working with the scientists and constructing knowledge through modelling allow them to truly assimilate the results. The participants said they had a better perception of the interactions between the various elements of the system, the complexity of the management of the sluices, their positive effects on fish and kayak movement or the uselessness of certain weirs. For some participants, this way of sharing knowledge would even be a means to change the modes of public action. 'The infused science delivered in meetings does not make it possible to appropriate things. And it is just how we can join projects. In thematic commissions in the CLE there are exchanges but no co-construction. One could imagine the life of a $\mathrm{SAGE}^{2}$ with tools allowing a real implication' (Chamber of Agriculture).

In the BRIE'eau project, attention is also paid to questions such as 'How do we learn?' or 'What could have facilitated this learning?'. The underlying assumption is that some tools would facilitate certain types of knowledge; for example, the scenario-building approach would lead to the construction of knowledge and technical skills, while the role-playing game is more likely to facilitate political, relational and communicational learning. These learning effects are less expected results and are often made invisible when trying to evaluate them. However, they are likely to influence public action - the way in which the actors of a territory discuss and decide together.

These experiments make it possible to mobilize other types of data in the debates and to advance the discussions. 'The ABAC project has enabled us to fill the obvious gap in baseline data on organic agriculture and to interpret its environmental effects in terms of water quality' (said by a PIREN-Seine researcher). By instrumentalizing approximately 15 typical crop rotations on different pedo-climatic conditions, the scientists aimed to obtain, within a comparatively short period of time, scientifically original results that would also be useful from a societal point of view for regional policies. The Île-de-France region is mobilized to promote rural and peri-urban areas

\footnotetext{
${ }^{2}$ SAGE: water management scheme.
} 
but also seeks to quantify the services provided by organic farming. While consumer demand for organic products is steadily increasing, organic farming is not yet meeting demand in the Île-de-France region. The region is therefore determined to increase the proportion of organic farming to promote healthy and tasty food, at both the individual and the collective level, especially for school catering.

In the Grand Morin project, by playing with the interactive platform, elected officials and public services accepted the idea of only removing certain river weirs (while at the beginning of the experiment, elected officials did not want to remove any). 'Compromise should be to have some sections free and to deal with black spots of pollution with locks' (Mayor on the Grand Morin River). However, once the experiment was over, the actors resumed their strategic position, and some elected officials went back on weir removal discussed during the experiment. Finally, the weirs to be removed were chosen by the state services on the basis of criteria that were external to the local actors. Here we see the limits of participatory mechanisms to act on European regulatory standards imposed on local actors and the possibility of territorial innovation. Nevertheless, in 2014, the CLE of the Grand Morin River amended its watercourse management rules by recognizing both the heritage character of mill structures and its effects on river flow continuity and by asking property owners to manage them in winter in coordination with the public services.

It seems that this type of approach is able to create interest or a commitment from certain actors, which would then lead them towards a more operational reflection. However, in order to promote such effects, it is important to ensure continuity between this new participatory research space and the usual decision-making arenas in the region. For instance, in the BRIE'eau system, the main actors are the local community responsible for the catchment area, and the AQUI'Brie association is responsible for its animation. It is this latter actor - who has worked closely together on this applied research project - who will then be able to learn the lessons of this approach in the pursuit of his work of territorial animation.

\section{Conclusion}

\subsection{Evolution of the Programme and Scientific Methods}

The PIREN-Seine scientific practices have gradually evolved over 30 years. The programme was initially created at the request of river basin institutions to produce regulatory science to improve the quality of the Seine River. Scientists soon understood that basic scientific knowledge was lacking (e.g. on river processes, on water circulation) and that local issues could not be fully understood and resolved without a consideration of the whole basin territory. Hydrologists, geochemists and biogeochemists later realized that both the river network and the river basin that they were studying at time $\mathrm{t}$ were actually dependent on the past and present interactions of multiple actors and institutions and that history, geography, sociology, environmental policies and other disciplines needed to be part of the 
programme. Participatory social experiments were developed together with actors in the later phases, usually at the local level, using some of the tools (models, decision support systems) developed by the programme.

\subsubsection{Seine System Design}

The analysis of the Seine River system evolved from a consideration of the river hydrosystem (physical, chemical and ecological, including the connected waterbodies delimited by the basin boundaries) to a hydro-socio-ecosystem. It includes the river network, from headwater to the coast - the land-ocean continuum - the drainage basin, all human activities, institutions, regulations and the circulation of material, goods and products on the whole basin. Researchers were forced to recognize that this system is wide open to regional and global (transcontinental) effects (e.g. economics, regulations, consumer habits, production methods, import and export of products). For many products that characterize river quality and river fluxes, their circulation within the Seine basin is between one and two orders of magnitude higher than their export via the Seine River.

\subsubsection{Research Methods and the Position of Scientists}

The programme now includes three modes of research (question-oriented, fundamental and action research), with their various modes of valorization and exchange between three different communities (academics, river and basin stakeholders, local river users and managers) (Fig. 9). The PIREN-Seine has therefore developed a complex set of relationships with these communities on different levels: local with the general public, river associations and water commissions, basin-wide with institutions and global with peer scientists. Several types of products (scientific publications, reports to stakeholders, models and software, databases, leaflets and brochures, conferences, participatory meetings, etc.) are now generated by the programme, each adapted to a different audience. The current position of scientists with regard to the three communities is schematically presented in Fig. 9.

\subsubsection{Programme Governance}

From its inception, the project has been more on a bottom-up basis - conceived and elaborated by scientists with their counterparts at the institutions in question - than on a top-down basis, agreement between a dozen research institutions and as many stakeholders; therefore, its current governance is the result of 30 years of collaboration between a group of individual scientists and their individual counterparts among stakeholders: The research agenda is mostly generated by scientists, then discussed at the basic level and, finally, proposed and adopted by the funding partners. The current links between scientific financial partners, local actors and the scientific 


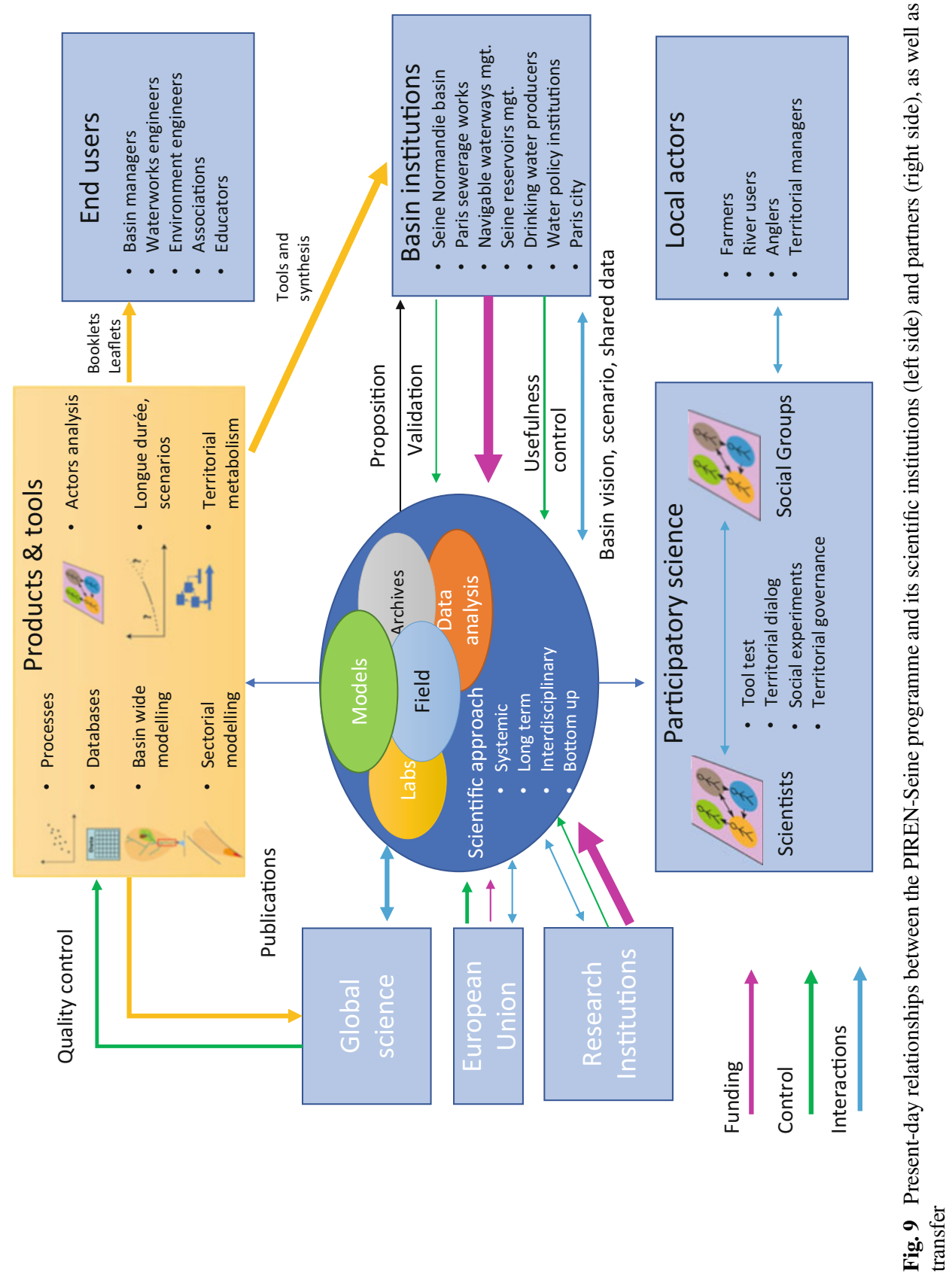


community show the growing complexity of a programme of this kind (Fig. 9). As such, the PIREN-Seine has survived many institutional transformations in the field of environmental research and is now one of the oldest continuous programmes in this field.

\subsubsection{Uses of Programme Outputs}

The scientific outputs of the programme are now used in multiple ways:

- Models are used by the river authority to produce missing water quality data, to simulate future trends of many water quality indicators (e.g. basic chemistry, fish circulation) with different scenarios for each waterbody, as defined by the WFD. They are also used for river management planning at the local and basin-wide levels. Land-to-ocean models are also used as input to coastal zone models. The PIREN-Seine's model cascade of N, P, C and Si, from the plot scale to the ocean and from the past 70 years to the next 50 years, has no equivalent in other basins.

- Specific studies have been done on basic water quality on the whole river network, and chemical and microbiological impacts of Paris megalopolis, as requested by institutional partners 30 years ago. Their outputs can now be used to question preventive vs. curative environmental solutions, and production vs. consumption strategies (e.g. for agrochemicals, cosmetics).

- The project has numerous pioneering studies on both a national and an international level. In addition to the model cascade, the following investigations are particularly worthy of note: (1) the basin-wide coupling of surface and groundwaters within the context of climate change; (2) the detection of emerging contaminants such as antibiotics and microplastics; (3) the basin-wide history and circulation of persistent contaminants from sediment archives; and (4) longue durée greenhouse gas budget for a river basin territory.

\subsection{Scientific Knowledge and Action}

Scientific knowledge and action are linked but in a complex way. Action can be taken without the production of knowledge, and knowledge does not always trigger action. Actors must be regularly informed about scientific progress in a suitable way to generate action. Scenarios built up by scientists and their partners must be discussed by members of the river basin committee (the deliberative level). Many water quality issues have not been, or could not be adequately, addressed in the past by scientists due to a lack of fundamental research (e.g. in the field of ecotoxicology and long-term effects of low-level contamination on human health); technical means (lack or limitation of analytical means for most micropollutants before the 1990s; lack of GIS before the 1990s); or available databases (e.g. the historical population database was only completed in the mid-1990s; most databases on material 
circulation are only available at the national level). Finally, the necessary multidisciplinary character of environmental sciences was largely lacking in France when the programme began.

\subsubsection{Knowledge Issues to Be Addressed in the Future}

The programme has identified many remaining issues that will need to be addressed in future phases, such as:

- Modelling the transfer of particulate microcontaminants in rivers

- Analysing transfer of contaminants across trophic levels

- Coupling physicochemical quality and ecological quality, as measured by the WFD, and its modelling

- Coupling high-frequency chemistry records with models

- Linking river/water quality and human health, now and in the past based on reconstituted archives

- Taking into account perception, evaluation and representation of the quality of the river and water resources, now and in the past, within and outside the regulatory domain

- Developing scenarios of future expectations of the public and water actors regarding the waterbodies and the basin in the context of global change and changing expectations, such as the increasing interest in the recreational use of rivers by the public, for example, river bathing in urban rivers

The continuity of the PIREN-Seine programme in the near future will therefore depend on several conditions: (1) ensuring up-to-date mono- and multidisciplinary research recognized at an international level; (2) continuing to develop tools and devices usable by the funding partners; (3) ensuring the dissemination of research to the various end users; (4) developing activities and research across scales, from local river issues to questions relating to the entire basin and the land-ocean continuum; and (5) continuing to consider socio-ecosystem trajectories over a wide time window (200 years and more) - reconstruction of the past, present observations and nearfuture scenarios.

\subsubsection{PIREN-Seine Governance Challenges}

Since the PIREN-Seine operates on a voluntary basis and at the individual/smallteam level and not at the laboratory/research-institution level, the programme will need to seek suitable scientists willing to fill these gaps in the future, as has been done so far at each of the seven stages of the programme (see [38]). Ecologists will join the next stage of the programme (2020-2023) to study the effects of changes in water circulation as a result of human activities on terrestrial ecosystems and biodiversity dynamics. PIREN-Seine researchers also want to work more closely with river managers and river users. During the flooding of the Seine in June 2016, 
they called on local residents to provide water samples taken from flooded banks in order to monitor contaminants [39]. The systematization of this participatory scientific approach would be particularly useful during extreme events that measuring stations are unable to monitor. However, a network of individuals may be difficult to set up due to the episodic and random nature of events.

Another development for the next stage of the programme will be the formalization of researcher-user interaction to valorize on a local level the results of the measurement stations and the modelling outputs. This work has already been done with river managers to monitor the physical effects of weir removal on the Orge River [40]. These initiatives of co-construction and valorization of research results will be continued at selected experimental sites (urban rivers around Paris, the Bassée floodplain $\left.\left(150 \mathrm{~km}^{2}\right)\right)$.

It will also be the task of stakeholders to ensure that these issues meet the expectations of the partners, always driven by regulatory constraints (e.g. ecosystemic services, effects of restoration of aquatic continuity on biodiversity, priority pollutants, good ecological state, etc.) with new issues arising (river water warming, 2024 Olympic Games) and the involvement of new partners (see [41]). The challenge is to take into account as accurately as possible the multiplicity of uses and points of view on the Seine basin socio-ecosystem and the resulting management complexity, as well as to achieve a shared vision of the hydrosystem as a common asset subject to public action, within a co-construction involving all actors.

Acknowledgements This work is a contribution to the PIREN-Seine research programme (www. piren-seine.fr), which belongs to the Zone Atelier Seine part of the international Long-Term SocioEcological Research (LTSER) network.

\section{References}

1. Jasanoff S (1998) The fifth branch: science advisors as policy makers. Harvard University Press, Cambridge

2. Gibbons M, Limoges C, Nowotny $\mathrm{H}$ et al (1994) The new production of knowledge: the dynamics of science and research in contemporary societies. SAGE, London

3. Nowotny H, Scott P, Gibbons M (2006) Re-thinking science: mode 2 in societal context. In: Carayannis EG, Campbell DFJ (eds) Knowledge creation, diffusion, and use in innovation networks and knowledge clusters. A comparative systems approach across the United States, Europe, and Asia. Praeger, Santa Barbara, pp 39-51

4. Hatchuel A (2000) Intervention research and the production of knowledge. In: LEARN Group (ed) Cow up a tree. Knowing and learning for change in agriculture. Case studies from industrialised countries. INRA, Paris, pp 55-68

5. Flipo N, Lestel L, Labadie P et al (2020) The Seine River basin. In: Flipo N, Labadie P, Lestel L (eds) The Seine River basin. Springer, Cham. https://doi.org/10.1007/698_2019_437

6. Dmitrieva T, Lestel L, Meybeck M et al (2018) Versailles facing the degradation of its water supply from the Seine River: governance, water quality expertise and decision making, 1852-1894. Water Hist 10(2-3):183-205 
7. Ayrault S, Meybeck M, Mouchel JM et al (2020) Sedimentary archives reveal the concealed history of micropollutant contamination in the Seine River basin. In: Flipo N, Labadie P, Lestel L (eds) The Seine River basin. Springer, Cham. https://doi.org/10.1007/698_2019_386

8. Raimonet M, Vilmin L, Flipo $\mathrm{N}$ et al (2015) Modelling the fate of nitrite in an urbanized river using experimentally obtained nitrifier growth parameters. Water Res 73:373-387

9. Vilmin L, Flipo N, de Fouquet $C$ et al (2015) Pluri-annual sediment budget in a navigated river system: the Seine River (France). Sci Total Environ 502:48-59

10. Vilmin L, Flipo N, Escoffier $\mathrm{N}$ et al (2018) Estimation of the water quality of a large urbanized river as defined by the European WFD: what is the optimal sampling frequency? Environ Sci Pollut R 25(24):23485-23501. https://doi.org/10.1007/s11356-016-7109-z

11. Tamtam F, Mercier F, Le Bot B et al (2008) Occurrence and fate of antibiotics in the Seine River in various hydrological conditions. Sci Total Environ 393(1):84-95

12. Lestel L, Meybeck M, Thévenot D (2007) Metal contamination budget at the river basin scale: an original Flux-Flow Analysis (F2A) for the Seine River. Hydrol Earth Syst Sci 11 (6):1771-1781

13. Lestel $\mathrm{L}$ (2012) Non-ferrous metals $(\mathrm{Pb}, \mathrm{Cu}, \mathrm{Zn}$ ) needs and city development: the Paris example (1815-2009). Reg Environ Change 12(2):311-323

14. Meybeck M, Lestel L, Bonté P et al (2007) Historical perspective of heavy metals contamination $(\mathrm{Cd}, \mathrm{Cr}, \mathrm{Cu}, \mathrm{Hg}, \mathrm{Pb}, \mathrm{Zn}$ ) in the Seine River basin (France) following a DPSIR approach (1950-2005). Sci Total Environ 375(1):204-231. https://doi.org/10.1016/j.scitotenv.2006.12.017

15. Teil MJ, Tlili K, Blanchard M et al (2014) Polychlorinated biphenyls, polybrominated diphenyl ethers, and phthalates in roach from the Seine River basin (France): impact of densely urbanized areas. Arch Environ Contam Toxicol 66(1):41-57

16. Goutte A, Alliot F, Budzinski H et al (2020) Trophic transfer of PAH, phthalates, and their metabolites in an urban river food web. Environ Sci Technol (submitted)

17. Even S, Billen G, Bacq N et al (2007) New tools for modelling water quality of hydrosystems: an application in the Seine River basin in the frame of the water framework directive. Sci Total Environ 375:274-291

18. Le Noë J, Billen G, Garnier J (2017) Nitrogen, phosphorus and carbon fluxes through the French Agro-Food System: an application of the GRAFS approach at the territorial scale. Sci Total Environ 586:42-55. https://doi.org/10.1016/j.scitotenv.2017.02.040

19. Anglade J, Billen G, Garnier J (2015) Relationships for estimating $\mathrm{N}_{2}$ fixation in legumes: incidence for $\mathrm{N}$ balance of legume-based cropping systems in Europe. Ecosphere 3:37

20. Garnier J, Le Noë J, Marescaux A et al (2019) Long-term changes in greenhouse gas emissions from French agriculture and livestock (1852-2014): from traditional agriculture to conventional intensive systems. Sci Total Environ 660:1486-1501. https://doi.org/10.1016/j.scitotenv.2019. 01.048

21. Lazure P, Dumas F (2008) An external-internal mode coupling for a 3D hydrodynamical model for applications at regional scale (MARS). Adv Water Resour 31(2):233-250. https://doi.org/ 10.1016/j.advwatres.2007.06.010

22. Romero E, Garnier J, Billen G et al (2019) Modeling the biogeochemical functioning of the seine estuary and its coastal zone: export, retention, and transformations. Limnol Oceanogr 64 (3):895-912. https://doi.org/10.1002/lno.11082

23. Ruelland D, Billen G, Brunstein D et al (2007) SENEQUE: a multi-scaling GIS interface to the Riverstrahler model of the biogeochemical functioning of river systems. Sci Total Environ 375 (1-3):257-273

24. Chong N, Bach PM, Moilleron R et al (2017) Use and utility: exploring the diversity and design of water models at the science-policy interface. Water 9(12):983

25. Lestel L, Carré C (eds) (2017) Les rivières urbaines et leur pollution. Quae, Paris

26. Garnier J, Billen G (2016) Ecological processes and nutrient transfers from land to sea: a 25-year perspective. In: Glibert PM, Kana TM (eds) Aquatic microbial ecology and biogeochemistry: a dual perspective. Springer, Cham, pp 185-197

27. Billen G, Le Noë J, Garnier J (2018) Two contrasted future scenarios for the French agro-food system. Sci Total Environ 637-638:695-705. https://doi.org/10.1016/j.scitotenv.2018.05.043 
28. Garnier J, Marescaux A, Guillon S et al (2020) Ecological functioning of the Seine River: from long term modelling approaches to high frequency data analysis. In: Flipo N, Labadie P, Lestel L (eds) The Seine River basin. Springer, Cham. https://doi.org/10.1007/698_2019_379

29. Le Pichon C, Gorge G, Faure T et al (2006) Anaqualand 2.0: freeware of distances calculations with frictions on a corridor. https://www6.rennes.inra.fr/sad/Outils-Produits/Outilsinformatiques/Anaqualand. Accessed 15 July 2019

30. Roy ML, Le Pichon C (2017) Modelling functional fish habitat connectivity in rivers: a case study for prioritizing restoration actions targeting brown trout. Aquat Conserv 27(5):927-937

31. Le Pichon C, Alp M (2018) Projet ANACONDHA. Analyse spatiale de la connectivité des habitats fonctionnels pour les poissons à l'échelle de l'estuaire. Rapport de recherche du programme Seine-Aval 5. https://www.seine-aval.fr/wp-content/uploads/2017/02/RR-SA5ANACONDHA.pdf. Accessed 15 July 2019

32. Wang S, Flipo N, Romary T (2019) Oxygen data assimilation for estimating micro-organism communities' parameters in river systems. Water Res 165:115021. https://doi.org/10.1016/j. watres.2019.115021

33. Benoit M, Garnier J, Beaudoin N et al (2016) A participative network of organic and conventional crop farms in the Seine Basin (France) for evaluating nitrate leaching and yield performance. Agr Syst 148:105-113

34. Carré C, Haghe JP, De Coninck A et al (2014) How to integrate scientific models to switch from flood river management to multifunctional river management. Int J River Basin Manag 12 (3):231-249. https://doi.org/10.1080/15715124.2014.885439

35. Tournebize J, Chaumont C, Mander U (2017) Implications for constructed wetlands to mitigate nitrate and pesticide pollution in agricultural drained watersheds. Ecol Eng 103:415-425

36. Gisclard M, Chantre É, Cerf M et al (2015) Co-click'eau: une démarche d'intermédiation pour la construction d'une action collective locale? Nat Sci Soc 23:3-13

37. De Coninck A (2015) Faire de l'action publique une action collective: expertise et concertation pour la mise en œuvre des continuités écologiques sur les rivières périurbaines. Dissertation, Université Paris Est

38. PIREN Seine Seine Teams. https://www.piren-seine.fr/fr/les-equipes. Accessed 15 Sept 2019

39. Flipo N, Mouchel JM, Fisson C (2017) Les effets de la crue de juin 2016 sur la qualité de l'eau du bassin de la Seine, vol 17. PIREN-Seine, Paris. Available via PIREN-Seine. https://www. piren-seine.fr/fr/fascicules/les-effets-de-la-crue-de-juin-2016-sur-la-qualité-de-leau-du-bassinde-la-seine. Accessed 15 Aug 2019

40. Bellot C (2014) Evolution du fonctionnement sédimentologique et biogéochimique d'un bief de rivière suite à l'effacement d'ouvrages hydrauliques. Dissertation, Université Pierre et Marie Curie

41. PIREN-Seine Partners. https://www.piren-seine.fr/fr/partenaires. Accessed 15 Sept 2019

Open Access This chapter is licensed under the terms of the Creative Commons Attribution 4.0 International License (http://creativecommons.org/licenses/by/4.0/), which permits use, sharing, adaptation, distribution and reproduction in any medium or format, as long as you give appropriate credit to the original author(s) and the source, provide a link to the Creative Commons licence and indicate if changes were made.

The images or other third party material in this chapter are included in the chapter's Creative Commons licence, unless indicated otherwise in a credit line to the material. If material is not included in the chapter's Creative Commons licence and your intended use is not permitted by statutory regulation or exceeds the permitted use, you will need to obtain permission directly from the copyright holder.

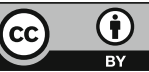

